\title{
Karakteristik Morfometrik Itik dan Produksi Telur Itik di Sentra Peternakan Itik Kabupaten Tolitoli
}

\section{Morphometrics Characteristic and Egg Production of Duck in Center Farming Area in Tolitoli Regency}

\section{Henrik*, Marhayani, Fajar Syadik}

Sekolah Tinggi Ilmu Pertanian Mujahidin Tolitoli, Jl. Samratulangi No 51, Kabupaten Toli-Toli, Provinsi Sulawesi Tengah, Indonesia

\begin{abstract}
Article history
Received: Feb 20, 2021;

Accepted: Aug 17, 2021

* Corresponding author:

E-mail:

hendrikaprawi@gmail.com

DOI:

10.46549/jipvet.v11i3.189

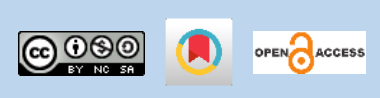

Abstract

This research aimed to identify the morphometrics characteristic and egg production of duck in the center farming area in Tolitoli Regency. There are four districts chosen as the research sample location, which are Dampal Selatan, Lampasio, Galang, and Dako Pemean. In each district, 250 female ducks were used. Parameters was observed is body weight, body length, pubis width, shank length, chest circumference, wings length, neck length, and egg production based on Hand Day Production. The correlation between morphometrics and HDP analyzed by IBM Statistic 25 software. The results showed that pubis width have a strong positive correlation with egg production ( $\mathrm{r}$ value $0.37-0.45$ ). The body weight have negative correlation with $\mathrm{HDP}(-0.31$ to -0.22$)$, chest circumference ( -0.13 to -0.05$)$, body length ( -0.01 to 0.03$)$, wing length $(-0.12$ to 0.03$)$, neck length (-0.03 to 0.02$)$, and shank length (0.02 to 0.03$)$. The morphometrics characteristic and egg production in duck center farming area are uniform with an HDP at $63 \%$.
\end{abstract}

Keywords: Correlation; Duck; Egg; Morphometrics; Production

\section{Abstrak}

Penelitian ini bertujuan untuk mengetahui karakteristik morfometrik dan produksi telur itik di sentra peternakan itik Kabupaten Tolitoli. Terdapat empat kecamatan yang dijadikan lokasi sampel pada penelitian ini yaitu Kecamatan Dampal Selatan, Lampasio, Galang, dan Dako Pemean dijadikan sampel penelitian. Masing-masing 250 itik betina yang digunakan. Parameter yang diamati yaitu bobot badan, panjang badan, lebar pubis, panjang shank, lingkar dada, panjang sayap, dan panjang leher serta produksi telur berdasarkan Hen Day Production (HDP). Hubungan morfometrik dengan produksi telur dianalisis menggunakan analisis korelasi menggunakan IBM Statistic 25. Hasil penelitian menunjukkan bahwa lebar pubis memiliki korelasi yang positif dan cukup kuat dengan HDP dengan nilai korelasi antara 0,37-0,45. Bobot badan berkorelasi negative dengan HDP $(-0,31$ sampai $-0,22)$, lingkar dada $(-0,13$ sampai $-0,05)$, panjang badan $(-0,01$ sampai 0,03$)$, panjang sayap $(-0,12$ sampai 0,03$)$, panjang leher $(-0,03$ sampai 0,02$)$, dan panjang shank $(0,02$ sampai 0,03$)$. Karakteristik morfometrik dan produksi telur itik pada sentra peternakan yang diteliti seragam dengan nilai HDP sebesar $63 \%$.

Kata kunci: Itik; Korelasi; Morfometrik; Produksi; Telur 


\section{PENDAHULUAN}

Itik lokal Indonesia memiliki keragaman morfometrik dan keragaman genetic yang tinggi (Purwantini et al., 2013; Henrik et al., 2018) sehingga menjadi salah satu sumberdaya peternakan yang harus dilestarikan. Itik lokal dikenal memiliki tingkat produksi yang beragam dan dapat menyesuaikan dengan kondisi pakan yang sesuai dengan potensi wilayah (Ismoyowati and Purwantini, 2013). Kemampuan adaptasi ternak itik ini menjadi salah satu keunggulan sehingga banyak diusahakan oleh masyarakat termasuk di Kabupaten Tolitoli.

Tingkat keragaman genetik dan pola pemeliharaan yang beragam di berbagai wilayah menghasilkan berbagai fenotip baik kuantitatif maupun kualititif ternak itik sehingga dapat dijadikan sebagai salah satu dasar pemuliaan. Pemuliaan ternak bertujuan untuk meningkatkan potensi genetic ternak yang didasarkan pada sifat-sifat tertentu. Pemuliaan ternak itik konvensional dapat didasarkan pada performa produksi dan kaitannya dengan sifat fenotip tertentu (Morduzzaman et al., 2016; Yakubu et al., 2015).

Produksi telur itik dapat dikaitkan dengan ukuran tubuh tertentu sehingga dapat digunakan sebagai dasar seleksi. Ismoyowati et al., (2006) melaporkan bahwa lebar pubis pada itik tegal sebagai salah satu sifat morfometrik memiliki koefisien korelasi sebesar 0,693 terhadap produksi telur. Pada itik Muscovy dilaporkan bahwa ukuran-ukuran tubuh, jenis kelamin, dan warna bulu juga memiliki hubungan yang erat dengan bobot badan (Ismoyowati et al., 2018).

Keragaman atau variasi dalam suatu populasi merupakan dasar pelaksanaan seleksi untuk pelaksanaan program pemuliaan ternak. Pada ternak unggas, variasi fenotip dilaporkan memiliki hubungan yang berkaitan dengan sifat-sifat produksi (Ismoyowati et al., 2006; Morduzzaman et al., 2016; Osei-Amponsah et al., 2013; Yakubu et al., 2015). Pada ternak itik variasi fenotip khususnya morfometrik semakin meningkat dengan kemunculan heterosis dari hasil persilangan resiprok (Henrik et al., 2018) yang kemungkinan berhubungan dengan sifat produksi. Identifikasi morfometrik juga dapat digunakan sebagai metode karakterisasi termasuk pada burung ayaman (Sada et al., 2018).

Xu et al., (2018) melaporkan bahwa bobot dan presentase daging dada pada ternak itik Pekin memiliki nilai heritabilitas sedang yaitu masing-masing 0.23 dan 0.16 sedangkan nilai heritabilitas bobot badan tergolong tinggi dengan nilai 0.48 . Hasil penelitian ini membuktikan bahwa bobot badan dan presentase daging dada dapat dijadikan sebagai dasar seleksi untuk meningkatkan bobot daging dada pada itik Pekin. Nilai heritabilitas juga sangat berhubungan dengan kecermatan seleksi untuk sifat produksi (Purwantini et al, 2016). Data fenotip kuantitatif seperti ini dibutuhkan untuk pengembangan system pemuliaan ternak itik dengan tujuan meningkatkan produksi.

Panjang leher, panjang digit ketiga, jenis kelamin, serta warna bulu juga memiliki pengaruh yang signifikan terhadap bobot badan itik Muscovy (Ismoyowati et al., 2018). Pemanfaatan sifat morfologi sebagai salah satu metode seleksi jangka panjang dapat digunakan untuk meningkatkan potensi itik Muscovy sebagai penghasil daging (Tamzil, 2018). Bobot badan ternak itik dilaporkan memiliki korelasi yang cukup tinggi dengan produksi dan bobot telur (Lin et al., 2016). Yakubu et al., (2015) juga melaporkan bahwa adanya korelasi bobot badan yang positif dengan ukuran tubuh lainnya. Hal ini menunjukkan bahwa ukuranukuran tubuh dan bobot badan dapat dijadikan sebagai salah satu strategi efisiensi seleksi untuk meningkatkan produksi ternak itik baik sebagai penghasil daging maupun telur.

Populasi ternak itik di Kabupaten Tolitoli dilaporkan berjumlah 69.007 ekor yang tersebar di sepuluh Kecamatan (BPS, 2018) namun karakteristik morfometrik dan tingkat produksi telurnya belum banyak dilaporkan. Penelitian ini bertujuan untuk mengetahui karakteristik morfometrik dan produksi telur itik di sentra peternakan itik di Kabupaten Tolitoli sehingga dapat dijadikan sebagai salah satu dasar seleksi dalam pemuliaan ternak konvensional. Penelitian ini juga diharapkan menjadi langkah awal pemetaan karakteristik ternak itik di Kabupaten Tolitoli yang dapat digunakan dalam pengembangan galur Itik Tolitoli sebagai salah satu sumberdaya genetic ternak lokal. 


\section{MATERI DAN METODE}

Penlitian ini menggunakan metode deskriptif yaitu menggambarkan keadaan yang sebenarnya terhadap objek penelitian dan parameter yang diamati sehingga data yang diperoleh adalah data pada keadaan yang sebenarnya tanpa memberikan perlakuan.

Penelitian ini menggunakan ternak itik milik peternak di Sentra Peternakan Itik di empat kecamatan di Kabupaten Tolitoli yaitu Kecamatan Dampal Selatan, Lampasio, Galang, dan Dako Pemean. Masing-masing sebanyak 250 ekor ternak itik betina dari masing-masing peternak dijadikan sampel dan diukur morfometrik dan produksinya.

\section{PARAMETER PENELITIAN DAN PROSEDUR PENGUKURAN}

Paramater penelitian terdiri dari bobot badan, panjang badan, lebar pubis, panjang shank, lingkar dada, panjang sayap, dan produksi telur dengan metode pengukuran sebagai berikut:

- Bobot badan: diukur dengan menggunakan timbangan berkapasitas $5 \mathrm{~kg}$ dengan tingkat ketelitian 10 gr;

- Panjang badan: diukur menggunakan meteran pendek antara panjang ujung Rostum maxillare sampai bagian ekor (Téguia et al., 2008);

- Lebar pubis: diukur berdasarkan jarak antara pubis kiri dan kanan (I. Ismoyowati \& Purwantini, 2013);

- Panjang shank: diukur berdasarkan panjang tulang metatarsus (Téguia et al., 2008);
- Lingkar dada: diukur di daerah bawah sayap di tepi sternum (Téguia et. al., 2008);

- Panjang sayap diukur berdasarkan jarak antara pangkal tulang humerus sampai tulang phalangens;

- Panjang leher diukur dari occipital condyles dan batan cephalic di coracoids;

- Produksi telur: diukur berdasarkan Hen Day Production (HDP) yaitu jumlah telur selama satu bulan dibagi dengan jumlah itik betina dan dikalikan seratus persen.

\section{ANALISIS DATA}

Data yang diperoleh dideskripsikan sesuai dengan hasil pengamatan dan pengukuran untuk menggambarkan karakteristik morfometrik dan produksi telur itik di sentra peternakan itik. Korelasi fenotipik dianalisis menggunakan analisis korelasi dengan menggunakan software IBM SPSS Statistic 25 untuk mengetahui keeratan hubungan antara karakteristik morfometrik dengan produksi telur.

\section{HASIL DAN PEMBAHASAN}

\section{KARAKTERISTIK MORFOMETRIK DAN PRODUKSI TELUR}

Berdasarkan penelitian yang telah dilaksanakan bahwa karakteristik morfometrik dan produksi telur itik di Sentra Peternakan itik di Kabupaten Tolitoli terdapat kemiripan sesuai yang disajikan pada Tabel 1.

Tabel 1. Rata-rata ukuran Morfometrik dan produksi telur itik di Sentra Peternakan Itik Kabupaten Tolitoli

\begin{tabular}{llcccc}
\hline & Karakteristik & \multicolumn{3}{c}{ Sentra Peteranakan Itik } \\
\cline { 3 - 5 } No. & Morfometrik & Kec. Dako Pemean & Kec. Galang & Kec. Lampasio & $\begin{array}{c}\text { Kec. Dampal } \\
\text { Selatan }\end{array}$ \\
\hline 1. & Bobot Badan (gr) & $1349,80^{* *} \pm 76,34$ & $1449,68 \pm 76,38$ & $1450,00 \pm 76,22$ & $1449,68 \pm 76,31$ \\
2. & Panjang Badan (cm) & $20,43 \pm 0,78$ & $20,50 \pm 0,70$ & $20,49 \pm 0,70$ & $20,49 \pm 0,69$ \\
3. & Lebar Pubis $(\mathrm{cm})$ & $5,03 \pm 0,48$ & $5,01 \pm 0,47$ & $5,00 \pm 0,46$ & $5,00 \pm 0,46$ \\
4. & Panjang shank $(\mathrm{cm})$ & $5,53 \pm 0,48$ & $5,52 \pm 0,46$ & $5,51 \pm 0,46$ & $5,51 \pm 0,46$ \\
5. & Lingkar Dada $(\mathrm{cm})$ & $25,92 \pm 0,81$ & $25,94 \pm 0,71$ & $25,97 \pm 0,71$ & $25,95 \pm 0,74$ \\
6. & Panjang Sayap (cm) & $22,99 \pm 0,76$ & $23,00 \pm 0,65$ & $22,99 \pm 0,72$ & $23,00 \pm 0,73$ \\
7. & Panjang Leher $(\mathrm{cm})$ & $18,99 \pm 0,66$ & $19,00 \pm 0,65$ & $18,99 \pm 0,64$ & $19,00 \pm 0,64$ \\
8. & HDP $(\%)$ & $63,50 \pm 0,66$ & $63,50 \pm 0,67$ & $63,46 \pm 0,67$ & $63,49 \pm 0,66$ \\
\hline
\end{tabular}

** Signifikan $(\mathrm{P}<0,01)$ pada baris yang sama 
Hasil penelitian menunjukkan bahwa karakteristik morofometrik seragam kecuali pada bobot badan. Performa fenotip yang homogen karena populasi itik yang dipelihara pada masing-masing sentra peternakan itik baik di Kecamatan Dako Pemean, Galang, Lampasio, dan Dampal Selatan berasal dari satu penyedia bibit yang sama yang berasal dari wilayah Kota Raya Kabupaten Parigi Moutong dan merupakan hasil persilangan antara itik Tegal dan Mojosari.

Bobot badan itik di sentra peternakan itik di Kecamatan Dako Pemean lebih rendah dibandingkan dengan kecamatan lain dalam penelitian ini diduga merupakan faktor umur ternak. Itik di Kecamatan Dako Pemean memiliki umur yang lebih muda (47 minggu) sedangkan itik di tiga kecamatan lainnya sudah berumur 68 minggu. Ketaren dan Prasetyo (2002) melaporkan bahwa pertambahan bobot badan itik hasil persilangan itik Tegal dan Mojosari pada pada awal pertumbuhan umur 8 minggu 887,5 gram. Bobot badan ini cenderung mengikuti bobot badan itik Mojosari dan diduga merupakan pengaruh genetik maternal dari itik Mojosari.

Pemeliharaan ternak itik di empat kecamatan adalah sistem pemeliharaan ekstensif. Di Kecamatan Galang, Lampasio, dan Dampal Selatan itik dipelihara di areal persawahan yang baru saja dipanen namun tetap ditunjang dengan pemberian pakan berupa dedak padi. Selain itu pemberian pakan juga ditunjang dengan pakan yang bersumber dari limbah rumah tangga seperti sisa nasi dan sayuran sedangkan di Kecamatan Dako Pemean itik sepenuhnya digembalakan dan tanpa diberikan pakan tambahan lain sehingga pertambahan bobot badan itik dapat lebih tinggi dibandingkan itik di sentra peternakan itik di Kecamatan Dako Pemean.

Produksi telur dari keempat lokasi sentra peternakan itik di Kabupaten Tolitoli diperoleh bahwa rata-rata produksi telur sebesar $63,48 \%$ berdasarkan Hen Day Production (HDP). Produksi telur pada penelitian ini lebih tinggi dari laporan Ketaren (2007) bahwa produksit telur itk gembala berkisar antara 26,9-41,3\%. Keseragaman tingkat produksi telur di sentra peternakan itik di Kabupaten Tolitoli ini diduga karena sistem pemeliharaan yang hampir sama antara sentra peternakan itik di empat kecamatan yang ada, yaitu dengan cara pemeliharaan itik berpindah menyesuaikan dengan masa panen padi pada areal pertanian sawah tempat penggembalaan. Produksi telur itik di Kecamatan Dako Pemean sama dengan di tiga kecamatan lainnya diduga karena umur itik di Kecamatan Dako Pemena lebih rendah. hal ini sesuai dengan laporan Subagja et. al., (2017) bahwa semakin tinggi umur itik maka produksi telurnya akan menurun.

Sistem pemeliharaan itik dengan sistem gembala dilaporkan berpengaruh terhadap tingkat produksi telur karena ketercukupan nutrien yang kurang optimal (Ketaren dan Prasetyo, 2002). Sistem penggembalaan secara langsung dapat meningkatkan lama durasi paparan sinar matahari terhadap itik sehingga pemanfaatan nutrien berkurang. Ma et al., (2014) melaporkan bahwa ternak itik yang terpapar suhu diatas $34^{\circ} \mathrm{C}$ dapat menurunkan konsumsi pakan dan frekuensi bertelur, meningkatkan panting, serta menurunkan kualitas telur yang terdiri dari bobot telur, kekuatan dan ketebalan cangkan telur, dan Haugh Unit. Lebih lanjut dilaporkan bahwa semakin tinggi tingkat stres panas yang dialami itik dapat menurunkan konsumsi pakan sebesar $11,9 \%$, penurunan HDP $7,3 \%$, dan penurunan bobot telur sebesar 2,9\%. Berbeda dengan sistem intesif dimana ternak dipelihara pada kandang yang tertutup sehingga dapat mengurangi paparan sinar matahari dan stres panas. Henrik dan Marhayani (2020) melaporkan bahwa itik HDP itik Mojosari yang dipelihara secara intensif antara 65,3-68,9\% dan bahkan dapat mencapai $74,09 \%$ (Ismoyowati dan Purwantini, 2013).

\section{KORELASI FENOTIPIK TERHADAP PRODUKSI TELUR}

Berdasarkan analisis korelasi terhadap ukuran morfometrik itik di sentra peternakan itik di Kabupaten Tolitoli menunjukkan bahwa karakteristrik morfometrik memiliki hubungan dengan produksi telur (Tabel 2).

Bobot badan itik secara signifikan $(\mathrm{P}<0,01)$ berkorelasi negatif terhadap produksi telur, meskipun hubungannya tergolong lemah. Bobot badan yang berkorelasi negatif terhadap produksi telur diduga berhubungan dengan ketersediaan dan pemanfaatan nutrien pakan yang dikonsumsi. Sistem pemeliharaan 
ekstensif yang diterapkan dengan ketersediaan pakan yang berasal dari sisa panen padi sawah kemungkinan tidak dapat maksimal dalam menunjang fungsi fisiologis itik untuk produksi telur tanpa harus kehilangan bobot badan. Dengan kata lain, keterpenuhan nutrient untuk produksi dan pertumbuhan tidak optimal, sehingga dalam proses metabolismenya terjadi mobilisasi protein dari jaringan-jaringan tubuh. Hubungan yang terbentuk antara bobot badan dengan produksi telur menunjukkan ketika produksi telur meningkat maka bobot badan akan turun, demikian pula sebaliknya jika bobot badan meningkat maka produksi telur akan turun.

Tabel 2. Korelasi fenotipik dengan produksi telur di sentra peternakan itik Kabupaten Tolitoli

\begin{tabular}{cccccc}
\hline \multirow{2}{*}{ No. } & Karakteristik & \multicolumn{3}{c}{ Sentra Peteranakan Itik } \\
\cline { 3 - 5 } & Morfometrik & $\begin{array}{c}\text { Kec. Dako Pemean } \\
(\mathrm{r})\end{array}$ & Kec. Galang (r) & Kec. Lampasio (r) & $\begin{array}{c}\text { Kec. Dampal } \\
\text { Selatan }(\mathrm{r})\end{array}$ \\
\hline 1. & Bobot Badan & $-0,290^{* *}$ & $-0,314^{* *}$ & $-0,224^{* *}$ & $-0,292^{* *}$ \\
2. & Panjang Badan & 0,029 & $-0,079$ & $-0,44$ & $-0,012$ \\
3. & Lebar Pubis & $0,441^{* *}$ & $0,367^{* *}$ & $0,450^{* *}$ & $0,401^{* *}$ \\
4. & Panjang shank & 0,022 & 0,033 & 0,023 & 0,027 \\
5. & Lingkar Dada & $-0,047$ & $-0,087$ & $-0,025$ & $-0,129^{*}$ \\
6. & Panjang Sayap & $-0,078$ & $-0,018$ & $-0,121$ & 0,025 \\
7. & Panjang Leher & $-0,032$ & $-0,028$ & 0,020 & $-0,032$ \\
\hline
\end{tabular}

*Signifikansi $\mathrm{P}<0,05 * *$ Signifikansi $\mathrm{P}<0,01$ pada baris yang sama

Lingkar dada, panjang sayap, dan panjang leher juga memiliki hubungan yang negatif terhadap produksi telur, namun tidak signifikan ( $P>0,05)$ dan tergolong lemah. Panjang badan berkorelasi positif namun sangat lemah, serta panjang badan yang berkorelasi negatif namun keduanya tidak signifikan $(\mathrm{P}>0,05)$. Satusatunya karakteristik morfometrik yang berkorelasi positif dan kuat terhadap produksi telur adalah lebar pubis $(\mathrm{P}<0,01)$. Lebar pubis memiliki hubungan kuat dan positif terhadap produksi telur. Korelasi lebar pubis terhadap produksi telur dari empat sentra peternakan itik di Kabupaten Tolitoli jika dirata-ratakan bernilai 0,415 yang artinya lebar pubis memiliki hubungan kuat dan signifikan terhadap produksi telur begitupun sebaliknya.

Lebar pubis dan produksi telur saling berkorelasi positif artinya semakin meningkat ukuran lebar pubis seiring dengan peningkatan produksi telur, demikian pula semakin meningkat produksi telur maka lebar pubis akan semakin besar. Meningkatnya ukuran lebar pubis seiring dengan peningkatan produksi diduga merupakan bentuk adaptasi morfologis yang menghasilkan perubahan lebar tulang duduk (Os pubis) karena letaknya yang berhubungan dengan saluran reproduksi. Ismoyowati et al., (2006) melaporkan bahwa lebar pubis memiliki korelasi positif yang kuat dengan produksi telur dengan nilai korelasi 0,693 .

\section{KESIMPULAN}

Penelitian ini menujukkan bahwa karakteristik morfometrik dan produksi telur di sentra peternakan itik Kabupaten Tolitoli cenderung seragam dan memiliki hubungan yang kuat khususnya pada lebar pubis dengan produksi telur, sedangkan karakteristik lainnya memiliki hubungan yang lemah dan negatif. Produksi telur pada sentra peternakan itik di Kabupaten Tolitoli dengan system ekstensif cukup tinggi yaitu mencapai HDP 63\%.

\section{UCAPAN TERIMA KASIH}

Terima kasih kepada Direktorat Jenderal Pendidikan Tinggi Kementerian Pendidikan dan Kebudayaan serta Lembaga Penelitian dan Pengabdian kepada Masyarakat Sekolah Tinggi Ilmu Pertanian Mujahidin Tolitoli yang telah memberikan pendanaan penelitian melalui kontrak 4329/LL9/PG/2020.

\section{DAFTAR PUSTAKA}

BPS. (2018) "Kabupaten tolitoli dalam angka 2018,” BPS Kabupaten Tolitoli. Tolitoli. 
Henrik dan Marhayani, M. (2020) "Egg production and quality of Magelang duck, Mojosari duck, and their reciprocal crosses," Jurnal Ilmu-Ilmu Peternakan, 30(3), hal. 180-183. https://doi.org/10.21776/ub.jiip.2020.030. 03.01.

Henrik, Purwantini, D., \& Ismoyowati. (2018) "Morphometrics and genetic diversity of Tegal, Magelang and their crossbred ducks based on Cytochrome b gene," Journal of the Indonesian Tropical Animal Agriculture, 43(1), hal. 9-18. https://doi.org/10.14710/jitaa.43.1.9-18.

Ismoyowati dan Purwantini, D. (2013) 'Produksi dan kualitas telur itik lokal di daerah sentra peternakan itik," Jurnal Pembangunan Pedesaan, 13(1), hal. 1116.

Ismoyowati, Yuwanta, T., Sidadolog, J. P. H., dan Keman, S. (2006). "Hubungan antara karakteristik morfologi dan performans reproduksi itik tegal sebagai dasar seleksi," J. Indon. Trop. Anim. Agric, 31(3), hal. 152-156.

Ismoyowati, dan Purwantini, D. (2013) "Egg production and quality of local ducks in ducks farming center area," Jurnal Pembangunan Pedesaan, 13(1), hal. 1116.

Ismoyowati, Susanto, A., Purwantini, D., Tugiyanti, E., dan Awalludin, A. N. (2018) "Morphometric traits and melanocortin 1 receptor (MC1R) gene polymorphism of Indonesian muscovy ducks of different plumage color population," International Journal of Poultry Science, 17(7), hal. 327-335.

https://doi.org/10.3923/ijps.2018.327.335.

Ketaren, P. P. (2007) "Peran itik sebagai penghasil telur dan daging nasional," WARATAZOA, 17(3), hal. 117-127.

Ketaren, P. P., dan Prasetyo, L. H. (2002) "Pengaruh pemberian pakan terbatas terhadap produktivitas itik silang mojosari $\mathrm{x}$ alabio (MA): 2. Masa Bertelur Fase Kedua Umur 44-67 Minggu," Jurnal Ilmu Ternak Dan Veteriner, 7(2), hal. 76-83.

Lin, R. L., Chen, H. P., Rouvier, R., dan MarieEtancelin, C. (2016) "Genetic parameters of body weight, egg production, and shell quality traits in the Shan Ma laying duck
(Anas platyrhynchos)," Poultry Science, 95(11), hal. 2514-2519. https://doi.org/10.3382/ps/pew222.

Ma, X., Lin, Y., Zhang, H., Chen, W., Wang, S., Ruan, D., dan Jiang, Z. (2014) "Heat stress impairs the nutritional metabolism and reduces the productivity of egg-laying ducks," Animal Reproduction Science, 145(3-4), hal. 182-190. https://doi.org/10.1016/j.anireprosci.2014 .01 .002 .

Morduzzaman, M., Bhuiyan, A., Rana, M., Islam, M., dan Bhuiyan, M. (2016) "Phenotypic characterization and production potentials of Nageswari duck in Bangladesh," Bangladesh Journal of Animal Science, 44(2), hal. 92-99. https://doi.org/10.3329/bjas.v44i2.26007.

Osei-Amponsah, R., Kayang, B. B., dan Naazie, A. (2013) "Phenotypic and genetic parameters for production traits of local chickens in Ghana," Animal Genetic Resources/Ressources Génétiques Animales/Recursos Genéticos Animales, 53, hal. 45-50. https://doi.org/10.1017/s20786336130002 71.

Purwantini, D., Ismoyowati, dan Santosa, S. A. (2016) "Estimation of selection accuracy and responses of the production characteristic using different selection intensity in magelang duck," Journal of the Indonesian Tropical Animal Agriculture, 41(2), hal. 61-69. https://doi.org/10.14710/jitaa.41.2.61-69.

Purwantini, D., Yuwanta, T., dan Hartatik, T. (2013) "Morphology and genetic diversity of mitochondrial DNA D-Loop region using PCR-RFLP analysis in magelang duck and other native duck," J. Indonesian Trop.Anim.Agric, 38(1), hal. 1-9.

Sada, Y. J., Warsono, I. U., dan Murwanto, A. G. (2018) "Sifat kualitatif, morfometrik, dan karkas burung ayaman (Gallirallus phillippensis) di Kampung Macuan Distrik Masni Kabupaten Manokwari," Jurnal Ilmu Peternakan Dan Veteriner Tropis (Journal of Tropical Animal and Veterinary Science), 8(1), hal. 19-26. https://doi.org/10.30862/jipvet.v8i1.30.

Subagja, H., Prasetyo, B., dan Nurjanah, H. (2017) "Faktor produksi usaha ternak itik 
petelur semi intensif di kabupaten jember production factor affecting layer duck bussiness of semi-intensive poultry farm in jember regency," Jurnal Ilmiah INOVASI, 17(2), hal. 67-72. https://doi.org/10.25047/jii.v17i2.545.

Tamzil, M. H. (2018) "Sumber daya genetik entok (Cairina moschata): Profil dan potensi produksi sebagai penghasil daging," WARTAZOA, 28(3), hal. 129138.

Téguia, A., Ngandjou, H. M., Defang, H., dan Tchoumboue, J. (2008) "Study of the live body weight and body characteristics of the African Muscovy duck (Caraina moschata)," Tropical Animal Health and Production, 40(1), hal. 5-10. https://doi.org/10.1007/s11250-007-90304.
Xu, Y., Hu, J., Zhang, Y., Guo, Z., Huang, W., Xie, M., Liu, H., Lei, C., Hou, S., Liu, X., dan Zhou, Z. (2018) "Selection response and estimation of the genetic parameters for multidimensional measured breast meat yield related traits in a long-term breeding Pekin duck line," AsianAustralasian Journal of Animal Sciences, 31(10), hal. 1575-1580. https://doi.org/10.5713/ajas.17.0837.

Yakubu, A., Muhammed, M., Ari, M., MusaAzara, I., dan Omeje, J. (2015) "Correlation and path coefficient analysis of body weight and morphometric traits of two exotic genetic groups of ducks in Nigeria," Bangladesh Journal of Animal Science, 44(1), hal. 1-9. https://doi.org/10.3329/bjas.v44i1.23112. 